\title{
Epizootic mortality in hatchery-reared lake trout Salvelinus namaycush caused by a putative virus possibly of the herpesvirus group
}

\author{
P. E. McAllister, R. L. Herman
}

U.S. Fish and Wildlife Service, National Fish Health Research Laboratory, Box 700, Kearneysville, West Virginia 25430, USA

\begin{abstract}
Althouch transmission studies showed that an infectious agent was involved in an epizootic mortality in hatchery-reared fingerling and yearling lake trout Salvelinus namaycush, routine diagnostic examinaticns repeatedly failed to detect infectious or parasitic agents. Histological examination consistently showed epithelial hyperplasia inside the mouth, on the snout, and over the body. Electron microscopy revealed a putative virus associated with the hyperplastic tissue; however, the virus has yet to be isolated in cell culture. Morphologically, the virus resembled a herpesvirus, bu: its taxonomic grouping has yet to be firmly established. In laboratory studies, the infection could be transmitted by cohabitation with diseased fish, by exposure to water from tanks holding diseased fish, and by bath challenge with filtrates $(0.45 \mu \mathrm{m}$ and $0.22 \mu \mathrm{m})$ of hyperplastic epidermal tissue. As judged from laboratory challenges and hatchery observations, the disease did not appear to affect brook trout Salvelinus fontinalis, brown trout Salmo trutta, rainbow trout Salmo gairdneri, or Atlantic saimon Salmo salar.
\end{abstract}

\section{INTRODUCTION}

In January 1986, unexpected, serious mortality occurred in yearling lake trout Salvelinus namaycush, 10 to $11 \mathrm{~cm}$ long, after routine tagging operations at the Iron River (Wisconsin, USA) National Fish Hatchery $(\mathrm{NFH})$. Soon thereafter, similar losses were seen in fingerling lake trout ( 3 to $4 \mathrm{~cm}$ long) at the hatchery. Other state and Federal lake trout hatcheries in the Great Lakes region have reported similar losses since 1983.

Clinically, moribund fingerling and yearling lake trout became lethargic, rode high in the water, and showed sporadic flashing and corkscrew diving activity. Hemorrhages occurred in the eyes and occasionally the mouth, and gray-white mucoid blotches appeared on the skin and fins. Hematocrits were elevated (mean 45.6) in acutely affected fish. Secondary fungus infections developed on the eyes, fins, and in patches on the body surfaces of survivors. Mortality approached 100\% in fingerling fish.

Initial diagnostic examinations of dead and moribund lake trout failed to show the consistent presence of any particular infectious agent or parasite. Although Pseudomonas sp. was isolated from material beneath fungal lesions and from the kidneys of some moribund lake trout, these infections were considered secondary because isolation was not consistent, the bacterium is ubiquitous, and the results of histologic examination were not compatible with a bacterial infection. Environmental toxicity was suspected as the cause of the losses, but the mortality pattern suggested instead that an infectious process was involved. We determined that the mortalities were indeed caused by an infectious agent, as judged by the results of transmission studies and electron microscopic examinations. The purpose of this report is to document our findings on the etiology of the lake trout disease.

\section{MATERIALS AND METHODS}

Fish. Fingerling and yearling lake trout showing signs of the disease were obtained from Iron River NFH. Healthy lake trout fingerlings were obtained from Allegheny (Pennsylvania, USA) NFH, Pendills Creek (Michigan, USA) NFH, and the National Fishery Research and Development Laboratory (Pennsylvania, USA). Healthy, fingerling brook trout Salvelinus fontinalis, brown trout Salmo trutta, and rainbow trout 
Salmo gairdneri were obtained from White Sulphur Springs (West Virginia, USA) NFH, and healthy, fingerling Atlantic salmon Salmo salar from Green Lake (Maine, USA) NFH. All stocks of fish were held in spring water, either ambient $\left(12^{\circ} \mathrm{C}\right)$ or chilled $\left(9^{\circ} \mathrm{C}\right)$, and were fed U. S. Fish and Wildlife Service open formula trout feed (GR) or Atlantic salmon diet (ASD2).

Transmission. Trials were performed to demonstrate disease agent transmission by cohabitation, by exposure to waterborne infectious material, and by challenge with filtrates of infected tissue. To test transmission by cohabitation and by the waterborne route, we held healthy fingerling fish, free and in baskets, in static water aquaria and in flow-through tanks containing diseased lake trout. in the statıc water aquaria (54 I), $40 \%$ of the water was replaced daily; in the flowthrough tanks (15 l), spring water $\left(1 \mathrm{l} \mathrm{min}^{-1}\right)$ was supplied at 9 or $12^{\circ} \mathrm{C}$. In another experimental design, we put diseased lake trout in the top tank of a 2 -tank cascade flow system and put healthy fingerlings in the downstream tank so that water from the diseased fish flowed to the healthy fish. Negative control fish were held in separate aquaria or tanks.

For challenge with tissue filtrates, 20 healthy fingerling fish were placed in 11 aquaria and exposed for $5 \mathrm{~h}$ to filtered homogenates of skin from diseased lake trout or to filtered homogenates or sonicates of skin scrapings from diseased lake trout. The infection protocol has been described by McAllister \& Owens (1986). During exposure, feed was withheld and gentle aeration was provided. Control groups for these challenges were exposed to phosphate-buffered saline (PBS, pH 7.2) or to skin scrapings or homogenates from healthy lake trout.

To test for species specificity, we exposed groups of 20 each of healthy fingerling brook, brown, and rainbow trout and Atlantic salmon to diseased lake trout, using the cohabitation and waterborne challenge procedures described above. Negative control fish were held in separate aquaria or tanks: one group was held isolated and the other was exposed to healthy lake trout.

Preparation of skin tissue used in challenges. Skin was removed from dead or moribund fish, minced, resuspended in PBS, and homogenized for 1 to $2 \mathrm{~min}$ in a Virtis blender. In some experiments the homogenate was then sonicated at 75 to $100 \mathrm{~W}$ for 10 to $20 \mathrm{~s}$. The homogenate was clarified by centrifugation at $1500 \times \mathrm{g}$ for 20 min at $4{ }^{\circ} \mathrm{C}$. The supernatant fluid was collected and passed through $10,5,3$, and $0.8 \mu \mathrm{m}$ average pore diameter (apd) membrane filters, respectively, before being passed 3 times through $0.45 \mu \mathrm{m}$ apd membrane filters. In some instances the homogenate was then passed 3 times through $0.22 \mu \mathrm{m}$ apd membrane filters.
Skin scrapings were similarly processed. Filtrates were tested for bacterial contamination by inoculation of fluid thioglycollate broth that was then incubated at 25 and $37^{\circ} \mathrm{C}$. (They were found to be sterile.)

Serial challenge experiments.To determine whether a filter-passing, replicating agent explained the lake trout mortalities, 2 serial passage experiments were undertaken. In one, $0.45 \mu \mathrm{m}$ apd skin filtrates served as the inoculum for the challenge; in the other, $0.22 \mu \mathrm{m}$ apd skin filtrates were used. In both experiments, the filtrates were prepared, as already described, from the skin of dead or dying lake trout with typical signs of the disease; also, the bath method, described above, was used for administering the challenge. At each challenge, 20 healthy lake trout fingeriings were used, and when they died, identical skin filtrates were prepared from them and used to challenge another lot of healthy fish. In this way, 3 lots of healthy fish were serially challenged. Controls for these experiments consisted of healthy lake trout fingerlings challenged with PBS or with skin filtrates prepared from healthy lake trout.

Histology. Moribund and healthy fish were euthanized with tricaine methanesulfonate (MS-222). Selected tissues were dissected from larger fish and fixed in Bouin's solution or $10 \%$ formalin; smaller fish were fixed whole after the abdominal cavity had been opened. Specimens were processed into paraffin, and 4 $\mu \mathrm{m}$ sections were prepared using routine methods and stained with hematoxylin and eosin, May-Grundwald Giemsa, or MacCallum-Goodpasture procedures.

Electron microscopy. Samples of snout, gills, spleen, anterior and posterior kidney, and blood were taken from diseased and control lake trout. The specimens were fixed in $4 \%$ glutaraldehyde in Millonig's buffer $(\mathrm{pH} 7.3)$, washed twice in buffer, and postfixed in $1 \%$ $\mathrm{OsO}_{4}$. The preparations were then dehydrated in a graded ethanol series and infiltrated and embedded i.n. Spurr's low viscosity medium. Thin sections (10 to $20 \mathrm{~nm}$ ) were stained with uranyl acetate and lead citrate and examined using a Hitachi H600 electron microscope at an accelerating voltage of $75 \mathrm{kV}$.

Filtered $(0.45$ and $0.22 \mu \mathrm{m}$ apd) skin scrapings and skin homogenates or their cesium chloride gradient fractions were loaded into a Beckman airfuge EM90 rotor and particulates sedimented onto formvar-coated 400 mesh copper electron microscopy grids by centrifugation for $20 \mathrm{~min}$ at $30 \mathrm{psi}\left(2 \times 10^{5} \mathrm{~Pa}\right)$. Grids were negatively stained in $4 \%$ uranyl acetate and examined as described above

Cell cultures. Stocks of CHSE-214, EPC, FHM, McCoy, and RTG-2 cell lines were maintained in Eagle's minimum essential medium (MEM) containing $10 \%$ fetal bovine serum and $100 \mu \mathrm{g} \mathrm{m} \mathrm{m}^{-1}$ gentamicin (MEM-10G). Primary cell cultures of lake trout caudal 
peduncle were initiated by using the trypsinization method of Wolf \& Quimby (1976) and were maintained in MEM conaining $20 \%$ fetal bovine serum and $100 \mu \mathrm{g}$ $\mathrm{ml}^{-1}$ gentamicin (MEM-20G).

Cell culture infectivity assays. Samples of snout, gills, kidneys, and spleen were assayed individually. Tissues were homogenized in a chilled mortar and pestle and suspended at 1:10 (wt vol'-1) dilution in MEM-20G. Debris was removed by centrifugation at $1500 \times g$ for $30 \mathrm{~min}$ at $4^{\circ} \mathrm{C}$. Supernatant fluids were brought to final 1:30 and 1:60 dilutions in MEM-20G. Preformed cell monolayers were drained and then inoculated with the diluted supernatant fluid $(0.3 \mathrm{ml}$ per $35 \mathrm{~mm}$ dish), and replicate cultures were held for 2 $\mathrm{h}$ at 9,15 , and $18^{\circ} \mathrm{C}$ for adsorption. Cells were then overlaid with MEM-20G and incubated at the temperature used for adsorption. Cultures were observed for 21 $\mathrm{d}$ and then blind passaged by using the original inoculation protocol.

Some cell lines were inoculated by using procedures and media developed by Yong \& Paul (1986) for the detection of chlamydia. The cell monolayers were pretreated with DEAE dextran (30 $\left.\mathrm{gg} \mathrm{ml}^{-1}\right)$ in MEM-10 as modified by Yong \& Paul, and the inoculum was sedimented onto the monolayers by centrifugation at $1400 \times g$ for $60 \mathrm{~min}$ at $12^{\circ} \mathrm{C}$ and then overlaid with modified MEM-10. Cultures were observed and blind passaged as described above.

\section{RESULTS}

\section{Transmission}

Mortality occurred in healthy lake trout fingerlings exposed to moribund lake trout or to filtered skin homogenates or skin scrapings from moribund lake trout. For lake trout exposed by cohabitation or by waterborne infectivity, clinical signs appeared about $7 \mathrm{~d}$ after exposure at $12^{\circ} \mathrm{C}$ and about $9 \mathrm{~d}$ after exposure at $9^{\circ} \mathrm{C}$. The mortality that followed was total by $15 \mathrm{~d}$. No mortalities occurred in control groups.

For lake trout exposed to filtered skin homogenates and scrapings, infectivity passed through 0.45 and 0.22 um apd membrane filters. Clinical signs appeared 5 to $7 \mathrm{~d}$ after exposure at $12{ }^{\circ} \mathrm{C}$, and mortality was total by 9 to $15 \mathrm{~d}$. The infection was serially passaged through lake trout 3 times, and the same clinical signs and histological changes seen in the hatchery epizootics were observed at each passage. No mortalities occurred in control groups.

No brown trout, rainbow trout, or Atlantic salmon challenged by cohabitation or by the waterborne route died during the $60 \mathrm{~d}$ of exposure to diseased lake trout at 9 and $12^{\circ} \mathrm{C}$. One of 20 brook trout in each group died several days after exposure, but death could not be attributed to the disease in the lake trout. No fish in the control groups died.

\section{Histopathology}

Pathology seen in moribund lake trout from transmission studies was the same as as that in naturally infected lake trout at Iron River NFH. Regardless of the method of exposure, characteristic areas of epithelial hyperplasia with lymphocytic infiltrates, hydrophic cells, and necrosis were found (Fig. 1). In fish in early stages of the infection, these lesions were more easily found near the oral flap. In late stages of the infection, any external epithelium could be affected. Gross manifestation of severe histological lesions was the grayish patches on the body and fins. Gill pathology was inconsistent because many gills appeared healthy.

Macrophages laden with cellular debris were common in the kidneys (Fig. 2) and could be found in the liver sinusoids in advanced cases of the disease. Vacuole patterns of hepatocytes invariably indicated greatly reduced glycogen reserves. Changes indicating osmotic upset were seen in some kidneys but were inconsistent in type and degree.

\section{Cell culture assays}

Cell culture assays of snout epithelium, gills, kidneys, and spleen with 5 different cell lines, each incubated at 3 temperatures, showed no evidence of cytopathogenic virus either on primary inoculation or on blind passage. Similarly, attempts to isolate virus by using protocols developed for detection of chlamydia were unsuccessful. Electron micrographs of inoculated and control cell cultures showed no evidence of virus, virus-like particles, or inclusion bodies.

\section{Electron microscopy}

In naturally infected and experimentally infected lake trout, electron microscopy revealed ellipsoidal to spherical particles in hyperplastic epidermal tissue of the snout. These particles were, however, not observed in gills, spleen, anterior or posterior kidneys, blood, or snout tissue below the epidermal layer. Two types of particles were observed. One was 130 to $175 \mathrm{~nm}$ in diameter, and had a diffuse electron-dense nucleoid 75 to $100 \mathrm{~nm}$ in diameter and a tailpiece about $140 \mathrm{~nm}$ long; this particle was seen extracellularly and in cytoplasmic vesicles (Fig. 3). The second was 150 to $200 \mathrm{~nm}$ in diameter, had a diffuse electron-dense nucleoid 75 to 


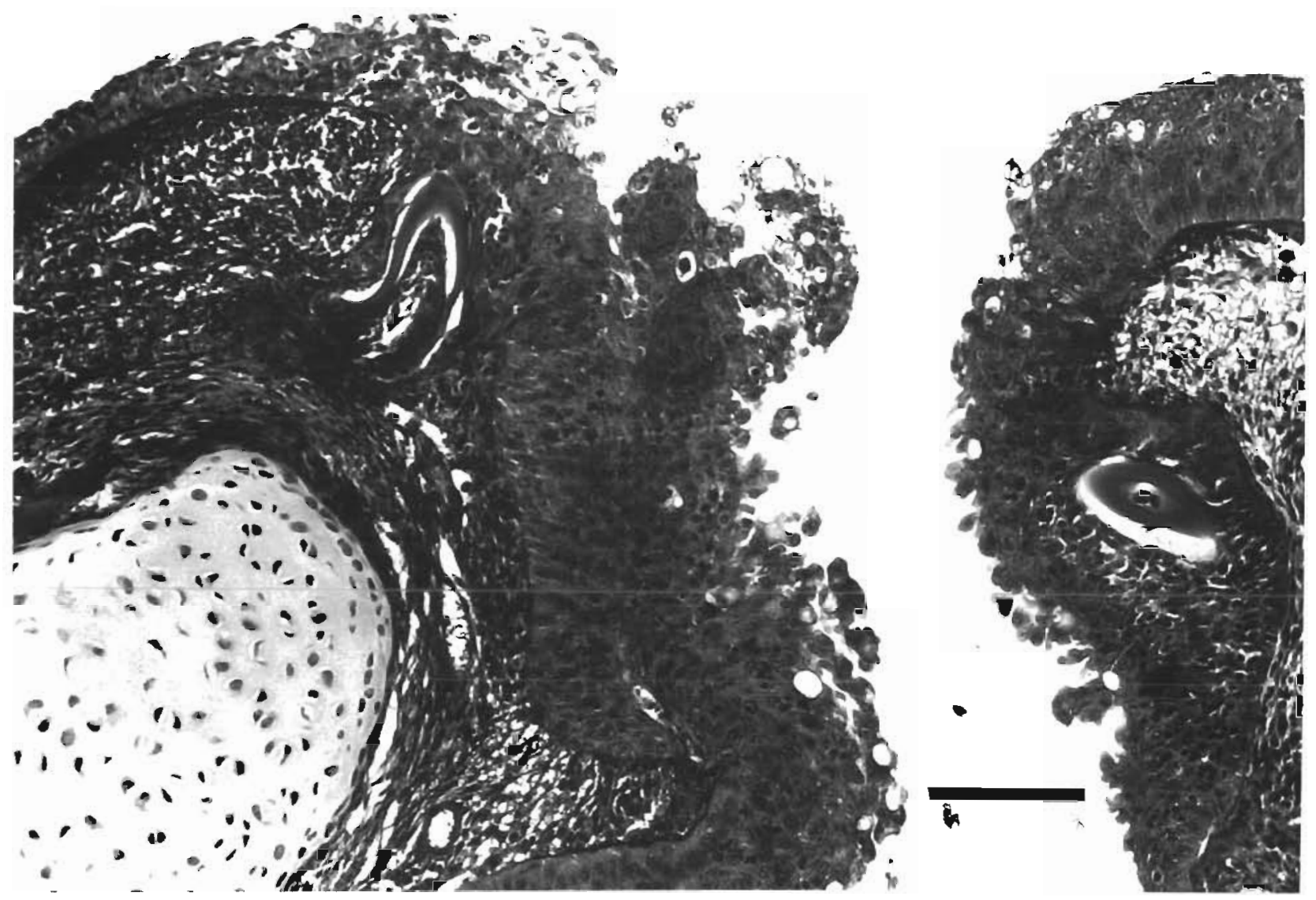

Fig. 1. Salvelinus namaycush. Sagittal section through the snout of a lake trout from epizootic at Iron River NFH, showing hyperplasia and necrosis of the epithelium. Bar $=100 \mu \mathrm{m}$

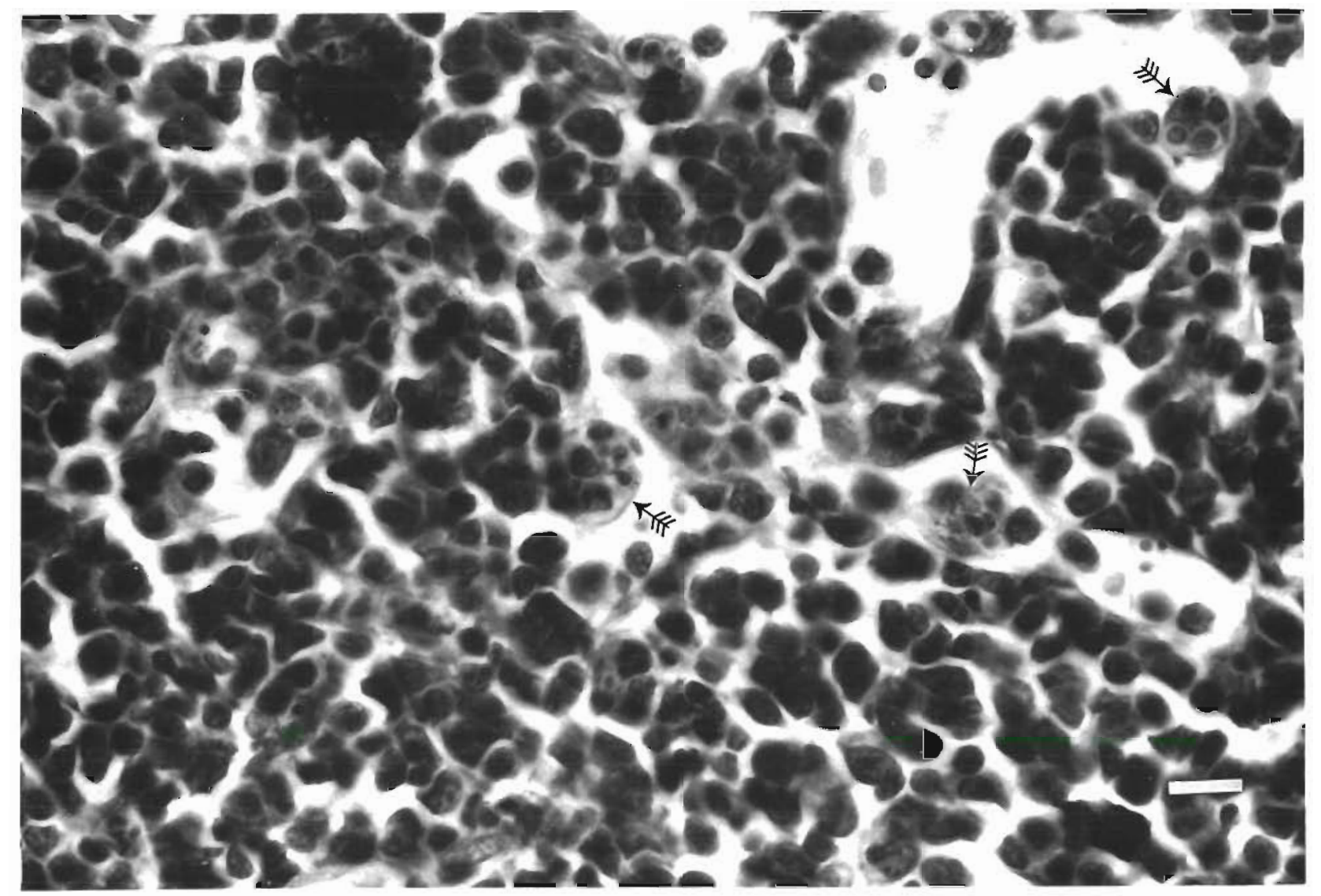

Fig. 2. Salvelinus namaycush. Section of anterior kidney from a lake trout exposed to a diseased lake trout from Iron River NFH showing debris-laden macrophages (arrows). Bar $=15 \mu \mathrm{m}$ 


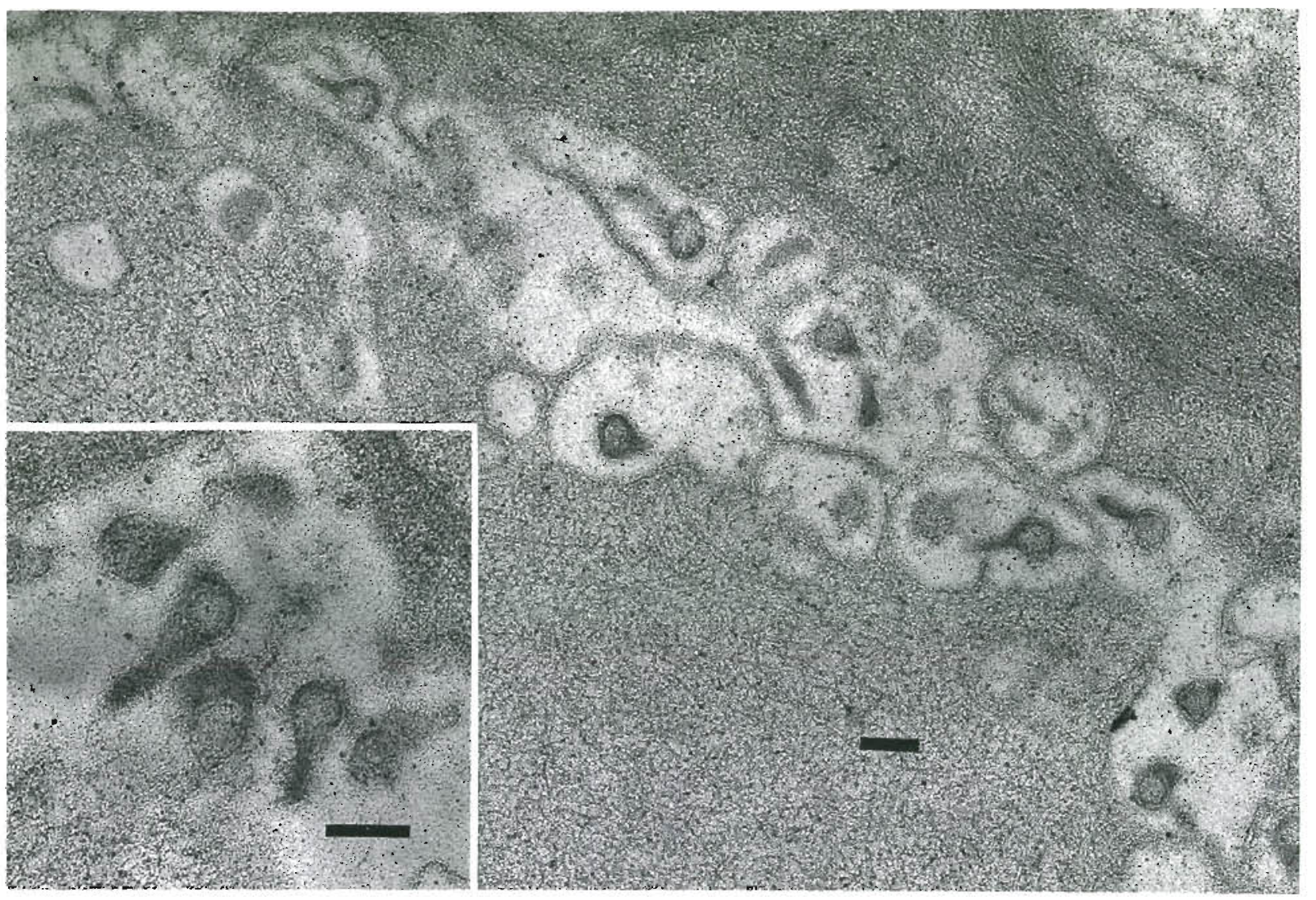

rig. 3. Salvelinus namaycush. Electron micrograph of a thin section of hyperplastic epidermal tissue from the snout of a diseased lake trout from Iron River NFH, showng putative herpesvirus particles Some particles have a tallpiece. Bars $=200 \mathrm{~nm}$

$100 \mathrm{~nm}$ in diameter, and was seen in cytoplasmic aggregates 2.5 to $4 \mu \mathrm{m}$ in diameter (Fig. 4). Both types of particles appeared to have an outer envelope. No such particles were seen in healthy fish.

\section{DISCUSSION}

For several years, lake trout mortality has been excessive at Federal and state hatcheries in the Great Lakes basin. Routine diagnostic examınations have repeatedly failed to identify the cause of the mortality, and the losses were usually attributed to nitrogen supersaturation or to toxicity. In the case we describe here, our transmission studies clearly showed that an infectious agent, a putative virus, was involved in the loss of lake trout at Iron River NFH. Our results and our observations at the hatchery suggest that the putative virus can be transmitted by fingerling, yearling, and brood stock lake trout and that it can be readily disseminated with contaminated hatchery equipment. The agent appears to be specific for lake trout because no mortality occurred in brown trout, raunbow trout, on
Atlantic salmon exposed to infected lake trout and because only negligible mortality occurred in exposed brook trout ( 1 of 20 fish in each of 2 trials). That brook, brown, and rainbow trout and Atlantic salmon were refractory to lethal infection does not preclude the possibility that these species could develop an inapparent infection; however, we have not seen the charactenstıc histological changes in in these species following exposure to diseased lake trout. In addition, we have not seen mortality in fingerling lake trout held with brook, brown, and rainbow trout that had previously been exposed to diseased lake trout in our cohabitation and waterborne infectivity transmission trals.

Hyperplasia of the epithelium is a consistent histopathologic change assoclated with the disease, and in thin sections of the hyperplastic epithelium we observed a putative virus. The agent we observed has the morphological charactenstics of a herpesvirus. At least 12 herpesviruses have been recognized in fish, and about half of the piscine herpesviruses are associated with epidermal lesions - dermatitis, hyperplasia, hypertrophy, and neoplasia (Wolf 1988). The 


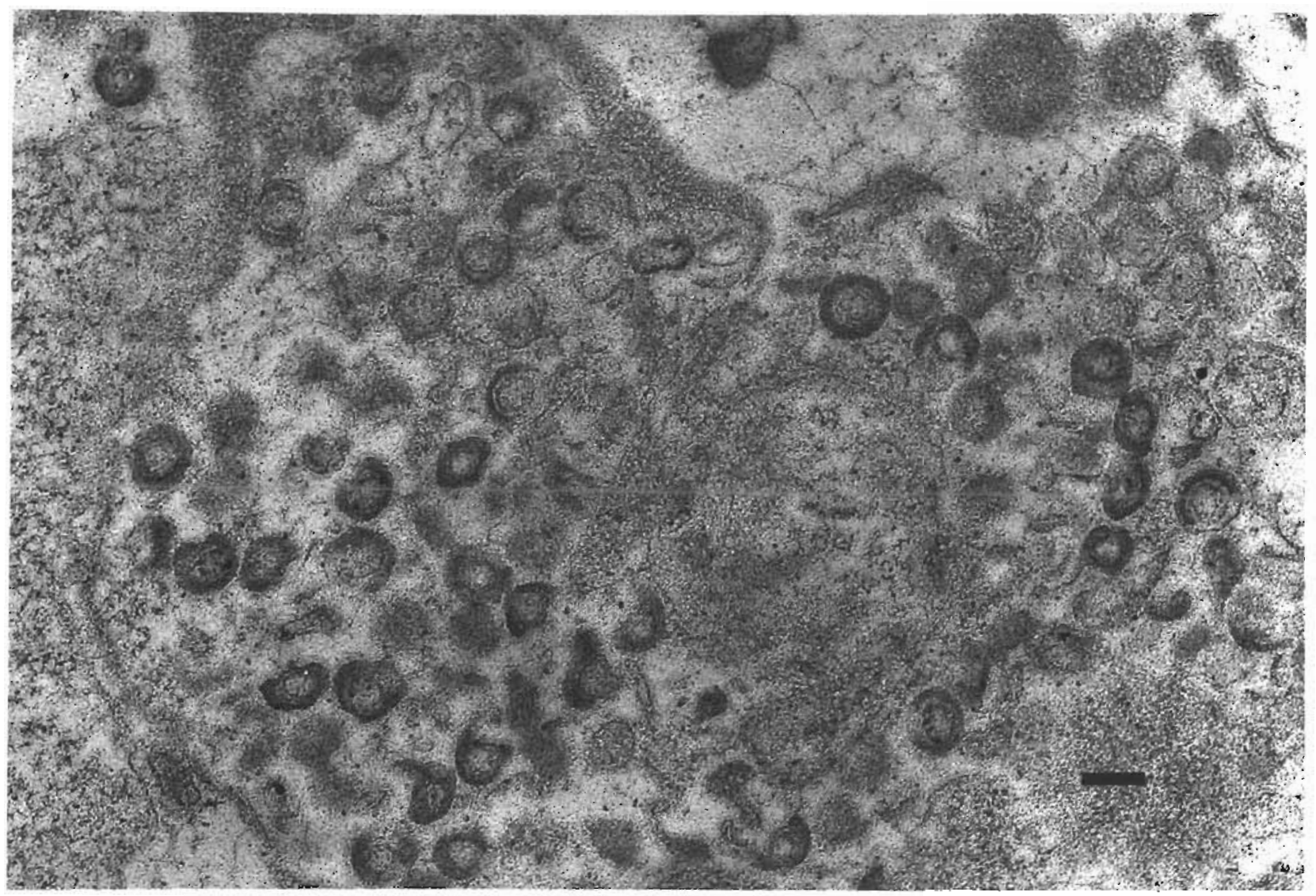

Fig. 4. Salvelinus namaycush. Electron micrograph of a thin section of hyperplastic epidermal tissue from the snout of a diseased lake trout from Iron River NFH, showing a cytoplasmic accumulation of putative herpesvirus particles. Bar $=200 \mathrm{~nm}$

enveloped virion we detected is 150 to $200 \mathrm{~nm}$ in diameter and has a diffuse electron-dense nucleoid 75 to $100 \mathrm{~nm}$ in diameter - dimensions similar to those reported for other piscine herpesviruses. The 2 types of particles we saw may be developmental forms, one being the virus released by budding from the cell surface and the other the as yet unreleased virus. The tailpiece we describe has been in both thin section and in negatively stained preparations of other piscine herpesvinuses (Anders \& Möller 1985, Buchanan \& Madeley 1978).

Originally, we described the virus as a chalmydialike organism (McAllister \& Herman 1987) because of its apparent similarity to epitheliocystis organisms described by Rourke et al. (1984). However, the virus we saw in the hyperplastic epidermis is less than half the size of that reported for epitheliocystis organisms in lake trout (Bradley et al. 1988a). Further, the histopathologic changes in lake trout with the disease are distinct from those of epitheliocystis. The latter infection is characterized by hypertrophied epithelial cells in the gills and skin (Herman \& Wolf 1987). In fact, in the moribund lake trout that we obtained from Iron
River NFH, we saw very little evidence of epitheliocystis ( 1 epitheliocystis cell on the gills of each of 2 of the many fish examined). Further, no epitheliocystis cells were seen in any of the mortalities resulting from our transmission studies.

Recently, Bradley et al. (1988b) reported detecting a virus about $110 \mathrm{~nm}$ in diameter in lake trout having a disease indistinguishable from the one we describe here. They named the disease viral epizootic epitheliotrophic disease. Their virus was detected in negatively stained preparations of gradient-fractionated material and is apparently the virus mentioned by Bradley et al. (1988a) in a 'Note Added in Proof'.

Buchanan \& Madeley (1978), in illustrating the ultrastructural details of a herpesvirus from turbot Scophthalmus maximus, showed electron micrographs of intact and disrupted virus. In electron micrographs of thin tissue sections, intact enveloped herpesvirus particles were clearly discemible - virus particles that were morphologically very similar to the virus we describe. In electron micrographs of negatively stained purified virus, the virions were shown to be stripped of their envelopes and appeared to have been disrupted 
by the purification process; these particles were morphologically very similar to the virus described by Bradley et al. (1988b). Thus, the virus we describe and that described by Bradley et al. (1988b) may indeed be the same entity. The morphological differences may be due to physical changes caused by our experimental protocols.

Our studies have clearly established that this disease in lake trout is caused by an infectious agent. The infectious agent seems to be a virus because we were able to serially reproduce the disease, using filtrates $(0.45$ and $0.22 \mu \mathrm{m}$ apd) of infected tissue. Electron micrographs of affected tissue suggest that the virus is a herpesvirus, but because we have not been able to isolate the virus in cell culture, it cannot now be definitively assigned to a specific taxonomic grouping.

Acknowledgements. We thank G. L. Bullock, P. E. Eschmeyer, C. L. Schultz, R. C. Simon, and K. E. Wolf for reviewing the manuscript; D. T Basch, D. E. Bowling, J. Ciak, W. J. Owens, and P. S. Whittington for technical assistance; R. C. Cipriano and C. E. Starliper for bacteriological examinations; H. M. Stuckey for photography; and R. B. Owens for secretarial assistance. We thank M. E. Wisniewski and W. L. Hershberger for technical assistance, helpful suggestions, and access to the electron microscope at the U. S. Department of Agriculture, Appalachian Fruit Research Station, Kearneysville, West Virginia USA. We also thank the staff of the Iron River (Wisconsin, USA.) NFH and the many other Federal and State fish hatcheries who gave willingly of their time and resources, the U. S. Fish and Wildlife Service (Region 3) for providing critical funding, and F. P. Meyer for his continued interest in the lake trout problem.

\section{LITERATURE CITED}

Anders, K., Möller, H. (1985). Spawning papillomatosis of smelt, Osnerus eperlanus L., from the Elbe estuary. J. Fish Dis. 8: 233-235

Bradley, T., Chang, P., Medina, D., McClain, J. (1988b). Viral epizootic epitheliotrophic disease of lake trout (Salvelinus namaycush). Am. Fish. Soc. Fish Health Section Newsletter 16: 2

Bradley, T M., Newcomer, C. E., Maxwell, K. O. (1988a). Epitheliocystis associated with massive mortalities of culture lake trout Salvelinus namaycush. Dis. aquat. Org. 4: 9-17

Buchanan, J. S., Madeley, C. R. (1978). Studies on Herpesvirus scophthalmi infection of turbot Scophthalmus maximus (L.) ultrastructural observations. J. Fish Dis. 1. 283-295

Herman, R. L., Wolf, K. (1987). Epitheliocystis infection of fishes. Fish Disease Leaflet 75. U. S. Fish and Wildlife Service, Washington, D. C., p. 1-4

McAllister, P. E., Herman, R. L. (1987). Chlamydia-like organism associated with high mortality in hatchery reared lake trout (Salvelinus namaycush). Am. Fish. Soc. Fish Health Section Newsletter 15: 6

McAllister, P. E., Owens, W. J. (1986). Infectious pancreatic necrosis virus: protocol for a standard challenge to brook trout. Trans. Am. Fish. Soc. 115: 466-470

Rourke, A. W., Davis, R. W., Bradley, T M. (1984). A light and electron microscope study of epitheliocystis in juvenile steelhead trout, Salmo gairdneri Richardson. J. Fish Dis. 7. $301-309$

Wolf, K. (1988). Fish viruses and fish viral diseases. Cornell University Press, Ithaca, New York

Wolf, K., Quimby, M. C. (1976). Primary monolayer culture of fish cells initiated from trypsinized tissues. TCA. (Tissue Culture Association) Manual 2: 453-456

Yong, D. C., Paul, N. R. (1986). Micro direct inoculation method for isolation and identification of Chlamydia trachomatis. J. clin. Microbiol. 23: 536-538 